\title{
The Word tapeinos in the New Testament and its Rendition in Ukrainian Translations
}

\author{
OLEXANDR LEVKO \\ Department of General Linguistics, Classical Philology and Neo-Hellenic Studies, \\ Taras Shevchenko National University of Kyiv, Volodymyrska 60, UA-01033 Kyiv \\ E-mail: o.levko@knu.ua
}

(Received: 19 April 2018; accepted: 11 July 2018)

\begin{abstract}
The paper addresses the rendition of the words denoting humility in six Ukrainian biblical translations of the 19th and 20th centuries. The author outlines the evolution of the semantics of tapeinos in Ancient Greek, Bible Greek, and New Testament Greek, identifying its contextual meanings in the New Testament. It is established that Ukrainian translations of the 19th century tend to use smyrennyi 'humble' and smyrennia 'humility' (as well as the outdated smyrnyi 'humble, mild', smyrnota 'humbleness', and smyrnist 'humility, mildness') to render the positive and neutral semantics of tapeinos and its nominal derivatives, while the translations of the end of the 20th and the 21st centuries mostly rely on pokirnyi 'submissive' and its cognates pokirlyvyi 'submissive', pokora 'submissiveness, obedience', pokirnist 'submission', though in some cases they also use sumyrnyi 'humble, peaceable' and the corresponding noun sumyrnist 'humility, humbleness' (but not smyrennia). When used in the negative meaning, tapeinos is rendered in modern biblical translations by prynyzhenyi 'humiliated', ponyzhenyi 'base', upokorenyi 'subdued' (occasionally by smyrennyi), whereas the translations of the 19th century do not take into account the negative connotations of tapeinos, and therefore render it by smyrennyi.
\end{abstract}

Keywords: translation, Ancient Greek, Ukrainian Bible, humility, New Testament

1. Humility is one of the main ethical values of Christianity, going back to the biblical image of the world (BUTTON 2005: 842). Despite the exceptional importance of humility in the system of Christian ethos, the essential meaning of this concept is open to discussion (RICHARDS 1988: 253-254, BUTTON 2005: 863-866, KeLLENBERGER 2010:323). It can be explained, on the one hand, by the complexity of semantics of words for humility in the Early Christian Greek literature, and on the other hand, by its evolution in the context of both religious and other types of discourse. Numerous studies emphasize the ambivalent character of the reception of humility in today's society (KeLlenBerger 2010: 321, HARE 1996: 235, DOBKO 2013: 53). In particular, its perception as a moral virtue for modern human is called in question (BUTTON 2005: 840). The authors who do regard humility as a value define this concept as "an inclination to keep one's accomplishments, traits, and abilities" (RICHARDS 1988: 256), "not overestimating one's worth or accomplishments" (FlaNAGAN 1990: 426), or "a disposition to avoid arrogance and boastfulness in spite of one's (justified) high self-assessment" (STATMAN 1992: 434), etc. 
Notwithstanding the debatable axiological status of humility, its biblical origin and construal as a value in the religious discourse of Christianity and Judaism is beyond doubt (see more in GreEn 1973, Nelson 1985, SCHLESINGER 1993, Koreneva 2010, Koch 2013, KonovalenKo 2014).

The lexicon of humility in modern European languages was formed, for the most part, under the influence of the sacral languages of Christianity: Greek and Latin. One of the main factors in the establishment of semantics of words denoting humility in European languages is their use in epochal biblical translations, which had an effect on the development of national languages. In ancient translations of the Holy Scripture, Greek words for humility were mostly rendered by their fixed equivalents without accounting for the contextual meanings of the source-language words (on the literalism of ancient translations, see more in GORBACHEVSKII 1996 KARPOV 2003). For example, in the Vulgate, the Greek words $\tau \alpha \pi \varepsilon i v \omega \sigma l \varsigma / \tau \alpha \pi \varepsilon l-$

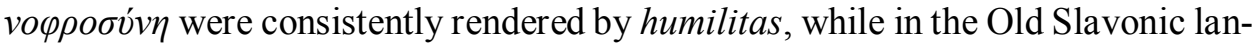
guage they were rendered by смирение/смиренномудрие. It is worth noting that the Greek words used to convey the semantics of humility have different contextual meanings in almost every verse of the New Testament, which accounts for the complexity of their accurate rendition in the translations without regard for all the discursive factors involved. However, modern translations demonstrate a tendency toward a careful selection of semantic equivalents for the source-language words (see more in BEEKMAN-CALLOW 1994), inasmuch allowed by the lexical capacities of the languages and the competence of the translator. While modern biblical translations do not have such a great effect on the development of the system of ethical values and their verbalization as, for example, the King James Bible or the Luther Bible do, we believe that studying the ways of rendition of the biblical lexis will promote the establishment of its use in target languages as well as the clarification of its semantics and elaboration of theological terminology in these languages (the rendition of various other biblical words in Ukrainian-language translations has been previously analyzed in Matskiv 2006, NimchuK 2011, Moroz 2012, LoBACHOVA 2015). The purpose of the present paper is to determine which lexical means are used in Ukrainian translations of the Bible to render the words for humility and to what extent they convey the semantics of the source terms. The study is based on Ukrainian translations by the following authors: I. Khomenko (IK); I. Ohiienko (IO); P. Kulish, I. Levytskyi, and I. Puliui (KLP); O. Hyzha (OH); P. Morachevskyi (PM); R. Turkoniak (RT).

2. In the New Testament and Early Christian texts, humility as a moral and ethical value is represented by the word $\tau \alpha \pi \varepsilon i v o \varphi \rho o \sigma v ́ v \eta$ ( 7 occurrences in the New Testament) as well as $\tau \alpha \pi \varepsilon i v \omega \sigma l \varsigma$, which, although mostly used with the meaning 'humiliation' (see Acts 8:33, Phil. 3:21, James 1:10), can also denote humility, particularly, meekness/obedience to God (see Luke 1:48). The word $\tau \alpha \pi \varepsilon ı v o \varphi \rho o \sigma v ́ v \eta$ is not typical of ancient authors, whereas $\tau \alpha \pi \varepsilon i v \omega \sigma l \varsigma$ appears in Ancient Greek literature only in the pejorative meaning 'misery', 'weakness', 'destitution' (SzRAM 2012: 328). In Early Christian and patristic literature, humility is represented by three lexemes - $\tau \alpha \pi \varepsilon \imath v o \varphi \rho o \sigma v ́ v \eta, \tau \alpha \pi \varepsilon l v o ́ \tau \eta \varsigma$, and $\tau \alpha \pi \varepsilon i v \omega \sigma l \varsigma$ - the last of which is 
characterized by broader semantics and denotes, apart from the virtue of humility, "a natural state of abasement of man as a created being" or "humiliation caused by sin" (SZRAM 2012: 342; cf. LAMPE 1961: 1373-1375).

In the New Testament, humility is viewed, on the one hand, as 'obedience to God', 'subjecting one's behaviour and thoughts to the will of God', and on the other hand, as 'the humility of mind', 'humility before people'. In the latter meaning, only the word $\tau \alpha \pi \varepsilon i v o \varphi \rho o \sigma v ́ v \eta$ 'humility', 'humility of mind' is used (see Phil. 2:3), which is defined by the authors as a "social value" (DicKSON-ROSNER 2004: 459-460) and interpreted as "a proper regard and respect for each other", "a selfless concern for the interests and welfare of others" (BLACK 1985: 302).

3. A whole array of words denoting humility, common in Early Christian literature, are derived from the adjective $\tau \alpha \pi \varepsilon \imath v o ́ \varsigma$, e.g. $\tau \alpha \pi \varepsilon \imath v o ́ \omega, \tau \alpha \pi \varepsilon i v \omega \sigma \iota \varsigma, \tau \alpha \pi \varepsilon l v o-$ $\varphi \rho o \sigma v ́ v \eta, \tau \alpha \pi \varepsilon \imath v o ́ \varphi \rho \omega v$. In Ancient Greek of the classical period, $\tau \alpha \pi \varepsilon \imath v o ́ \varsigma$ and the derivative words are widely used, though they mostly acquire negative connotations. In its initial meaning, $\tau \alpha \pi \varepsilon v v o ́ \varsigma$ is used with the semantics of space 'low' and 'bottomland' due to its etymology: $\tau \alpha \pi \varepsilon l v o ́ \varsigma$ probably comes from $\tau a ́ \pi o \varsigma$ 'lowland', 'depression' (cf. Lat. tempus 'temple') (GEW 2: 854, DELG 4: 1093). In its metaphorical meaning, $\tau \alpha \pi \varepsilon \imath v o ́ \varsigma$ is associated with a slave's position and the absence of civil rights and power, hence its use as a descriptor for people of low social status. Thus, when used to characterize a person, $\tau \alpha \pi \varepsilon \imath v o ́ \varsigma$ has the following meanings in ancient texts: 1. 'oppressed', 'relinquished of power'; 2. 'miserable', 'petty', 'weak'; 3. 'submissive'; 4. 'depressed', 'sad'; 5. 'mean', 'abject', 'foul' in the moral sense (DRS 2: 1602, GRS 1991: 1226, LSJ 1996: 1756-1757). Obviously, all the meanings above imply negative connotations.

As shown by many researchers, in classical works, $\tau \alpha \pi \varepsilon \imath v o ́ s$ marks unfavourable living conditions, slavery and submission to other people, depressed emotional state, humiliation, and absence of freedom (Sharbaugh 2013: 209, Volt 2003: 76, DiCKSON 2011: 89, FOULCHER 2015: 15-17). The manifold contexts of its use can

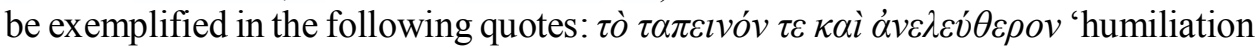

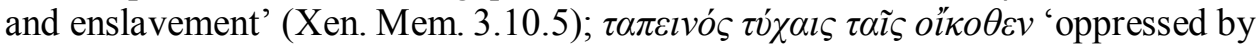

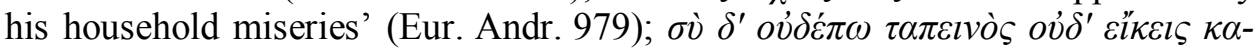
$\kappa o \tilde{\varsigma}$ 'you still have not subjected and yielded to the evil' (Aesch. Prom. 322);

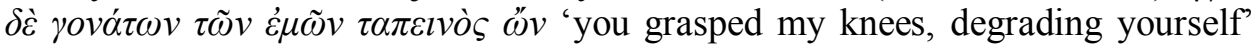

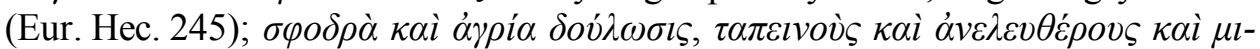
$\sigma \alpha \nu \theta \rho \omega ́ \pi \circ v \varsigma \pi \circ \imath \sigma \tilde{v} \sigma \alpha$ ' excessive and cruel subjection makes children wretched and enslaved man-haters' (Plato 1967: 791d).

Rare cases of positive connotations of $\tau \alpha \pi \varepsilon l v o ́ s$ prepare the ground for its use in the Septuagint and Early Christian literature. Particularly, in Laws by Plato we come across a sentence, where $\tau \alpha \pi \varepsilon l v o ́ \varsigma$ denotes a moral characteristic opposite to arrogance, impudence and bragging one's wealth: "She [Justice], again, is followed by every man who would fain be happy, cleaving to her with lowly ( $\tau \alpha \pi \varepsilon v v o ́ s)$ and orderly behaviour; but whoso is uplifted ( $\dot{\pi} \pi \alpha \rho \rho \dot{\mu} \mu v o \varsigma)$ by vainglory $(\mu \varepsilon \gamma \alpha \lambda \alpha v \chi i \alpha)$, or prideth himself on his riches or his honours or his comeliness of body, and through this pride joined to youth and folly, is inflamed in soul with insolence 
( $v^{\prime} \beta \rho \imath \varsigma$ ), dreaming that he has no need of ruler or guide, but rather is competent himself to guide others, such an one is abandoned and left behind by the God" (Plato 1967: IV 716a-b). In this passage, $\tau \alpha \pi \varepsilon \imath v o ́ \varsigma$ has the positive meaning of 'submissive', 'one who yields to authority'. The concept of submission/obedience is thus associated with orderliness, being aware of one's position in society and before the divinity. Humility acquires moral overtones, being counterposed with v" $\beta \rho \iota \varsigma$, which in the ancient times essentially denoted arrogance before divinity, losing one's awareness of the position one has in the changeable world, thus incurring gods' envy. To a certain extent, the semantics of $\tau \alpha \pi \varepsilon l v o ́ \varsigma$ in Plato is close to its contextual meanings in the Septuagint and the New Testament.

4. The word $\tau \alpha \pi \varepsilon l v o ́ \varsigma$ and its derivatives acquire new connotations in the Septuagint, the primary Greek translation of the Old Testament. The adjective $\tau \alpha \pi \varepsilon l v o ́ s$ is mostly used in the Septuagint as one of the equivalents of Hebrew words ani and anav, which have the contextual meanings of 'humble', 'submissive', 'miserable' (DAwes 1988: 338, Dickson-Rosner 2004: 461, Strong 1890: 6035). In the Old Testament, humility is mostly understood as submissiveness and obedience to God (DiCKSON-RosNer 2004: 459). People who are pleasing to God are often characterized as destitute and miserable ( $\tau \alpha \pi \varepsilon \imath v o i / \pi \rho \alpha \varepsilon \tilde{i} \varsigma)$ : they are the first to enjoy God's mercy and love (DAWES 1991: 38-39). In this meaning, $\tau \alpha \pi \varepsilon \imath v o ́ \varsigma$ is also used in the New Testament (e.g. in Luke 1:52). One of the few key passages of the Old Testament which contain certain analogies to the New Testament construal of humility is Zech. 9:9-10. It tells of the arrival of a humble king of the New Testament who will enter Jerusalem on a donkey, instead of on a horse as a war triumpher. In the Hebrew Bible, this passage features the word ani, while its equivalent in the Septuagint is $\pi \rho \alpha \tilde{\delta} \varsigma$, a partial synonym of $\tau \alpha \pi \varepsilon \imath v o ́ \varsigma$ as used in the New Testament.

J. Dickson and B. Rosner have found out that $\tau \alpha \pi \varepsilon \imath v o ́ \varsigma$ is not fully equivalent to the words ani ( 77 occurrences in the Old Testament) and anav (18 occurrences in the Old Testament): a whole array of words are used in the Septuagint to render the semantics of these Hebrew lexemes (cf. DicKSON-RosNer 2004). Hence, apart from $\tau \alpha \pi \varepsilon \imath v o ́ \varsigma$, ani is rendered by the adjectives $\pi \tau \omega \chi o ́ \varsigma$ 'poor', 'abject', 'destitute' (36 occurrences), $\pi \varepsilon ́ v \eta \varsigma$ 'poor', 'needy' (14 occurrences), $\pi \rho \alpha \ddot{o} \varsigma$ 'quiet', 'meek', 'affectionate', 'friendly' (4 occurrences), and $\dot{\alpha} \sigma \theta \varepsilon v \eta$ ऽ 'weak', 'petty', 'abject' ( 2 occurrences), while anav is rendered by $\pi \rho \alpha \ddot{v} \varsigma$ (7 occurrences), $\pi \tau \omega \chi o ́ \varsigma$ (3 occurrences), and $\pi \dot{v} v \eta \varsigma$ (3 occurrences) (DiCKSON-RosNer 2004: 462). In the Septuagint, the word $\tau \alpha \pi \varepsilon ı v o ́ \varsigma$ is used 11 times to render the Hebrew ani: in 9 cases, it has the meaning of 'abject', 'humiliated', 'oppressed', whereas in the other 2 cases, it has the meaning of 'humble/obedient to God'. It should be noted that ani is positively marked only in 5 cases out of 77; apart from $\tau \alpha \pi \varepsilon \imath v o ́ \varsigma$ (Ps. 17:2, Isa. 66:2), it is also rendered by $\pi \rho \alpha \ddot{o} \varsigma$ in 2 cases (Zech. 9:9, Zeph. 3: 12 and with $\pi \tau \omega \chi o ́ \varsigma$ in 1 case (2 Sam. 22:28) (DiCKSON-ROSNER 2004: 462). The adjective anav, which is cognate to ani, has positive connotations in 6 cases out of 18 but it is only rendered by $\tau \alpha \pi \varepsilon \imath v o ́ \varsigma$ once, while at other times it is rendered by $\pi \rho \alpha \ddot{v} \varsigma$ (DICKSON-ROSNER 2004: 476). Thus, in the meaning 'humble/submissive to God', $\tau \alpha \pi \varepsilon v v o$ ' is used in the Septuagint only 3 times (19\% of its general use in the Septuagint), while 
$\pi \rho \alpha \ddot{v} \varsigma$ is used in this meaning 7 times (64\% of its general use in the Septuagint). A humble person is viewed here as one 'who obeys Lord', 'who is afraid of God', 'who follows God's ways'. In the other cases, $\tau \alpha \pi \varepsilon l v o$ s has the meaning of 'abject', 'needy', 'destitute', and 'oppressed'.

5. In the New Testament, $\tau \alpha \pi \varepsilon ı v o ́ \varsigma$ appears in 8 cases: 2 times in the Gospels and 6 times in the epistles (Aland 1: 1242). Research has shown that its sense is not exclusively positive since in some cases it rather has the neutral ethical meaning 'needy', 'poor', 'destitute', instead of marking the virtue of humility (LEIVESTAD 1966: 45). In the Gospels, $\tau \alpha \pi \varepsilon l v o ́ \varsigma$ is featured in the word combination $\tau \alpha \pi \varepsilon l v o ̀ \varsigma$ $\tau \tilde{\eta} \kappa \alpha \rho \delta i \alpha$ 'humble in heart' (Matt. 11:29) and in the phrase $\kappa \alpha \theta \varepsilon \tilde{\imath} \varepsilon \varepsilon v \delta v v \alpha \dot{\sigma} \sigma \alpha \varsigma$

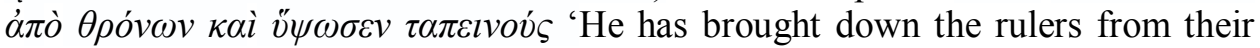
thrones and has lifted up the humble' (Luke 1:52), which is an allusion to Ezek. 21:31, Job 5:11, Ps. 147:6. According to Joseph Tayer, in Matt. 11:29, $\tau \alpha \pi \varepsilon ı v o ́ \varsigma$ means 'poor in spirit', 'humble', while in Matt. 11:29 it means 'poor', 'abject', 'needy' (TAYER 1886: 614). In the former case, the spiritual character of humility is underlined by the lexeme $\kappa \alpha \rho \delta i \alpha$, which is used throughout the Bible to mark the mental seat of feelings, emotions, virtues, and vices. This use has its parallel in the Septuagint, where $\tau \alpha \pi \varepsilon i v o ́ \varsigma$ is combined with the word $\pi v \varepsilon \tilde{\nu} \mu \alpha$ 'spirit': $\tau \alpha \pi \varepsilon i v o$ s $\tau \tilde{\omega} \pi v \varepsilon \dot{v} \mu \alpha \tau l$ 'crushed in spirit' (Ps. 33:19). Contrariwise, the meaning of this word in Luke 1:52 is 'poor', 'abject', 'destitute', 'oppressed', being firmly grounded in its Septuagint use (JORK 1991: 48, CAMERON 1999: 97). The semantics of $\tau \alpha \pi \varepsilon l v o ́ \varsigma$

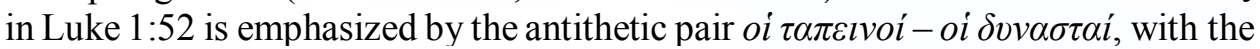
latter word meaning 'powerful', 'lord', 'ruler'. Probably, $\tau \alpha \pi \varepsilon i v o ́ \varsigma$ in this case should be interpreted not in the negative but in the neutral meaning.

In the epistles, $\tau \alpha \pi \varepsilon \imath v o ́ \varsigma$ also features in varying contextual meanings. Thus, in Rom. 12:16, the meaning of $\tau \alpha \pi \varepsilon v v o ́ \varsigma$ can be established from its antithetic con-

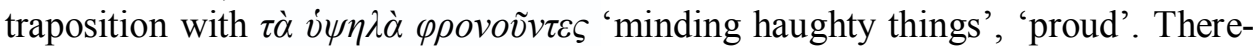
fore, $\tau \alpha \pi \varepsilon \imath v o ́ \varsigma$ concerns the mental field as a characteristic of people whose behaviour and self-image are far from arrogant and conceited. In this meaning, $\tau \alpha \pi \varepsilon i v o ́ \varsigma$ correlates with the use of $\tau \alpha \pi \varepsilon i v o \varphi \rho o \sigma v i v \eta$ in Phil. 2:3. However, in the Second Epistle to the Corinthians, $\tau \alpha \pi \varepsilon v v o ́ \varsigma$ acquires slightly different connotations. Par-

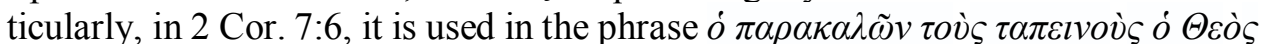
'God, who comforts the downcast /miserable/needy'. The context does not allow one to define the meaning of $\tau \alpha \pi \varepsilon v v o ́ \varsigma$ as 'not showing arrogance and self-importance'. The semantics of $\tau \alpha \pi \varepsilon ı v o ́ \varsigma$ in this case is likely to be closer to its Septuagint use, where $\tau \alpha \pi \varepsilon \imath v o ́ \varsigma$ mostly marks a person oppressed by circumstances and despised by other people whose only hope is God.

In Cor. 10:1, $\tau \alpha \pi \varepsilon l v o ́ \varsigma$ is once again used in an antithetic combination: $\kappa \alpha \tau \grave{\alpha}$

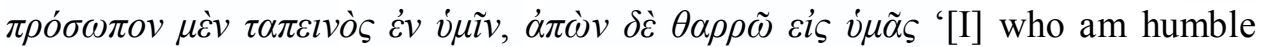
when face to face with you but bold toward you when absent'. In this context, the word $\theta \alpha \rho \rho \tilde{\omega}$ 'bold', 'daring' indicates the boldness and courage of the Apostle Paul's correspondence, while in front of the audience, he admonishes in a gentle way, as he puts it himself. Hence, in this verse, $\tau \alpha \pi \varepsilon \imath v o ́ \varsigma$ denotes the characteristic that is contrary to courage and boldness in communication and can be defined 
as caution in choosing one's words and a reserved approach to exposing others' vices. This contextual meaning of $\tau \alpha \pi \varepsilon i v o ́ \varsigma$ is emphasized by the use of $\pi \rho \alpha \ddot{v} \tau \eta \varsigma$

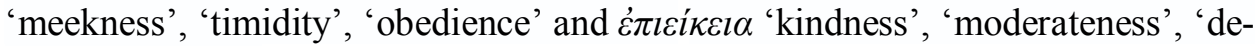
cency' next to it.

In the Catholic epistles, $\tau \alpha \pi \varepsilon \imath v o ́ \varsigma$ is used twice in contraposition with the word

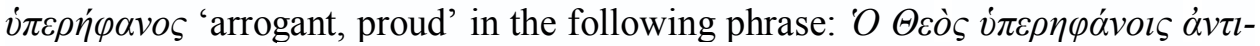
$\tau \dot{\alpha} \sigma \sigma \varepsilon \tau \alpha l, \tau \alpha \pi \varepsilon \varepsilon v \sigma \tilde{\imath} \varsigma \delta \dot{\varepsilon} \delta i \delta \omega \sigma l v \chi \alpha \dot{\alpha} \rho l v$ 'God opposes the proud but gives grace to the humble' (1 Pet. 5:5, James 4:6). Here, the word $\tau \alpha \pi \varepsilon \imath v o ́ \varsigma$ marks a person whom God favours and grants his mercy. Therefore, the opposition of $v \pi \varepsilon \rho \eta \dot{\eta} \varphi \alpha v o \varsigma$ 'arrogant' - $\tau \alpha \pi \varepsilon \imath$ vó $\varsigma$ 'humble' is construed not in the context of interpersonal relations but from the viewpoint of one's relations with God. God's aversion for those $v i \varepsilon$ -

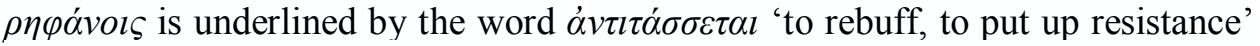
which here should be understood as a realization of the cognitive metaphor 'God is commander'. In this context, $\tau \alpha \pi \varepsilon \imath v o i$ come up as a community that God considers his own people. Obviously, the meaning of $\tau \alpha \pi \varepsilon i v o ́ \varsigma$ in 1 Pet. 5:5 and James 4:6 correlates with its semantics in the Septuagint (see Prov. 3:34).

The third appearance of $\tau \alpha \pi \varepsilon i v o ́ \varsigma$ in the Catholic epistles allows for its interpretation as an antonym to $\pi \lambda$ ov́ $\sigma ı \varsigma$ ' 'wealthy', which once again is closer to $\tau \alpha-$ $\pi \varepsilon \imath v o ́ \varsigma$ use in the Septuagint as an equivalent of ani 'poor', 'oppressed'. In James $1: 9$, the antithetic wordplay helps to convey the thought that a humiliated person should rejoice at the moments of his/her elevation, while a wealthy person has to rejoice at the moments of his/her humiliation. In general, here $\tau \alpha \pi \varepsilon l v o ́ \varsigma$ acquires the negative connotations 'oppressed by living circumstances', 'unfortunate', 'humiliated' and is relinquished of the positive semantics of mental submission to God or humility before people.

Hence, out of 8 occurrences of the use of $\tau \alpha \pi \varepsilon l v o ́ \varsigma$ in the New Testament, twice it has the negative meaning of 'humiliated', 'oppressed' (2 Cor. 7:6, James 1:9), which is typical of its use in the Septuagint, while in 6 other cases it has the positive or neutral meaning 'obedient to God', 'humble in one's mind / heart', 'unarrogant', and 'poor' (Matt. 11:29, Luke 1:52, Rom. 12:16, 2 Cor. 10:1, 1 Pet. 5:5, James 4:6).

6. In Ukrainian translations of the New Testament, the Greek $\tau \alpha \pi \varepsilon l v o ́ \varsigma$ is rendered by the following words: смиренний/сумирний/смирний and покірливий/ покірний. The adjectives смиренний/сумирний/смирний are etymologically cognate and come from Old Russian sъmerenъ/sъmirenı, which were used synonymously and had the meaning 'humble', 'meek', 'humiliated', 'tamed'. The variation in the roots szmer-/sbmir-, which can also be observed in the Old Slavonic language, was caused by the blending of two different stems in the Late ProtoSlavic period: sътёrъnъ (Ukr. смиренний) 'humble' (from mёra 'measure') and sъmirbnъ (Ukr. смирний) 'quiet', 'meek' (from mirb 'peace') (ESRJa 3: 688-689, ESUM 5: 322). According to the SUM, the word смиренний has two meanings: 1. 'one who is aware of one's worthlessness' or 'showing no arrogance'; 2. 'submissive', 'meek' (SUM 3: 404). In the second meaning, it overlaps with смирний 'submissive', 'meek' and сумирний 'submissive', 'meek', 'full of mildness and 
submission' (SUM 3: 405, 835-836). Obviously, only the word смиренний contains the semes that indicate the mental character of humility, whereas смирний and сумирний underline its result in action. With respect to the seme 'submissive' the words смиренний/сумирний/смирний are synonymous to покірливий /покірний, whose meaning is defined as 'one who always submits, concedes in everything, without making objections', 'obedient', 'subject to someone' (SUM 7: 25). The adjectives покірливий / покірний come from Proto-Slavic koriti 'tell off', 'humiliate', which in its turn comes from korz 'offence', 'despise' and cognate with Latin carino 'to ridicule', 'to disparage' (ESUM 3: 20). Therefore, in terms of the semantics of etymons, the Ukrainian words покірливий/покірний are close to the meaning of $\tau \alpha \pi \varepsilon l v o ́ \omega$ 'humiliate'.

All the lexemes that are used as the equivalents of the Greek $\tau \alpha \pi \varepsilon \imath v o ́ \varsigma$ in Ukrainian translations of the Bible are synonymously interconnected with relation to the seme 'realization of humility in action', 'subjection to someone's authority'. Contrariwise, the semes 'to consider oneself worse than others', 'to be of humble opinion about oneself' are only incidental to the adjective смиренний, which is thus the most accurate equivalent of $\tau \alpha \pi \varepsilon$ svós used in the New Testament in the meaning 'humble in one's mind / heart', 'unarrogant'.

As revealed by our comparative analysis of the Ukrainian translations of the New Testament, different translators can use all of the above adjectives in translating the same verse, which indicates - apart from the variability and the lack of stability in the use of Ukrainian equivalents of the Greek $\tau \alpha \pi \varepsilon$ ivó $\varsigma$ - the fact that contextual meanings of $\tau \alpha \pi \varepsilon l v o ́ \varsigma$ are not always accounted for by the translators. For example, in Matt. 11:29, the combination $\tau \alpha \pi \varepsilon v v o ̀ \varsigma \tau \tilde{\eta} \kappa \alpha \rho \delta i \alpha$ is rendered in a different way in 5 translations out of 6 :

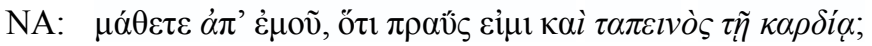
IO: навчіться від Мене, бо Я тихий і серием покірливий;
IK : навчіться від мене, бо я лагідний і сумирний серием;
$\mathrm{OH}:$ навчіться від Мене, бо Я покірний і сумирний серием;
RT: навчіться від Мене, бо Я лагідний і покірний серием;
KLP: навчіть ся від мене: бо я тихий і смирний серием;
PM: навчіться від Мене, бо Я тихий і смиренний серием.

In Luke 1:52, we encounter the same adjectives as in Matt. 11:29, though IK and PK use смиренний instead of сумирний and смирний, respectively. Therefore, in this verse, the contextual meaning of $\tau \alpha \pi \varepsilon l v o ́ \varsigma$ 'needy', 'poor', rooted in Hebrew anav, is not reflected in Ukrainian translations.

In the other 4 occurrences of its use (in the epistles), $\tau \alpha \pi \varepsilon l v o ́ \varsigma$ has the meaning 'humble', 'unarrogant', 'one who does not think highly of oneself' and is rendered in some of the translations by the words used in Matt. 11:29 and Luke 1:52, for example, in 1 Pet. 5:5 and James 4:6. However, in several translations we come across the words that are not, in our view, fully equivalent to $\tau \alpha \pi \varepsilon \imath v o$ $\varsigma$ in verses Rom. 12:16 and 2 Cor. 10:1, e.g. слухняний 'obedient', лагідний 'gentle', 'meek' and скромний 'modest': 
Rom. 12:16

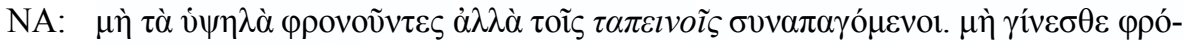

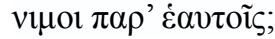

IO: не величайтеся, але наслідуйте слухняних; не вважайте за мудрих себе!;

IK: про високе не мудруйте, радше до покірного схиляйтеся; не будьте зарозумілі на себе;

ОН: не мудруйте зависоко, але наслідуйте сумирних; не підносьтеся в собі;

RT: не будьте зарозумілими, схиляйтесь до лагідних. Не вважайте себе замудрими;

KLP: Високо про себе не думайте, а до смиренних нахиляйтесь. Не бувайте мудрі самі в себе.

2 Cor. 10:1

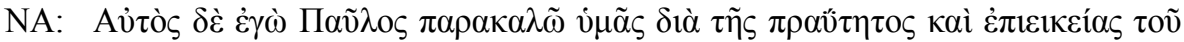

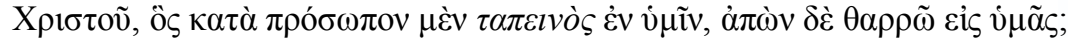

IO: А я сам, Павло, благаю вас лагідністю й ласкавістю Христовою; я, коли присутній слухняний між вами, а не бувши між вами сміливий я супроти вас;

IK: Я ж сам, Павло, особисто благаю вас лагідністю і ласкавістю Христа, я, коли присутній між вами, - покірний, а коли від вас далеко, сміливий супроти вас;

OH: А я, Павло, котрий особисто поміж вами скромний, а заочно супроти вас сміливий, переконую вас покірністю і ласкавістю Христовою;

RT: Сам же я, Павло, благаю вас лагідністю і покірністю Христовою; я, що присутній між вами, покірний, а відсутній - сміливий супроти вас;

KLP: Сам же я Павел благаю вас лагідностю і тихостю Христовою, а що в вічі смиренний між вами, а, не будучи між вами, сьміливий проти вас.

The use of the adjective скромний in 2 Cor. 10:1 can be explained with regard to the context of the verse as it addresses caution and moderateness in exposing the audience's vices.

In RT, $\tau \alpha \pi \varepsilon \imath v o ́ \varsigma$ is rendered by лагідний, which is mostly used as one of Ukrainian equivalents of $\pi \rho \alpha \hat{v} \varsigma$. Probably, the translator's choice was determined by the synonymic linkage between $\tau \alpha \pi \varepsilon i v o ́ \varsigma$ and $\pi \rho \alpha \ddot{o} \varsigma$ in the Septuagint and in the New Testament. However, the use of слухняний by IK in Rom. 12:16 and 2 Cor. $10: 1$, in our opinion, does not succeed in expressing the contextual meanings of $\tau \alpha \pi \varepsilon ı$ vós.

Although in 1 Pet. 5:5 and James 4:6, all of the five target lexemes are used in different translations, just as in Mt. 11:24, and the translators do not always use one lexeme in all 3 cases (except for $\mathrm{OH}$ and RT), e.g. IO uses смиренний twice (1 Pet. 5:5 and James 4:6) and покірливий once (Matt. 11:24), KLP uses смирний twice (Matt. 11:24 and James 4:6) and смиренний once (1 Pet. 5:5), while IK uses different lexemes in each of three occurrences: сумирний (Matt. 11:24), смиренний (1 Pet. 5:5) and покірливий (James 4:6). Taking into account the identity of verses 1 Pet. 5:5 and James 4:6 (which essentially cite Prov. 3:34), using different means to render $\tau \alpha \pi \varepsilon \imath v o ́ \varsigma$ in these cases does not seem appropriate. 
It should also be noted that the adjective $\tau \alpha \pi \varepsilon \imath v o ́ \varphi \rho \omega v$ 'one of humble mind', 'humble' (a cognate with $\tau \alpha \pi \varepsilon \imath v o \varphi \rho o \sigma v ́ v \eta$ 'the humility of mind', cf. Russian cмuренномудрие), which is used in 1 Pet. 3:8, is partly rendered by the same linguistic means as $\tau \alpha \pi \varepsilon ı v o ́ \varsigma$ in its positive/neutral meaning, particularly, покірливий (IO, $\mathrm{RT}$ ), смиренний (IK). However, in $\mathrm{OH}$, we encounter an attempt (not a successful one, in our view) to convey the internal form of $\tau \alpha \pi \varepsilon l v o$ ó $\rho \omega \nu$ by the word combination при здоровому глуздi 'of sound mind' (cf. смиренномудрый 'of humble mind' in ST), whereas KLP renders $\tau \alpha \pi \varepsilon \imath v o ́ \varphi \rho \omega v$ rather inaccurately by the word привітливий 'courteous'. Hence, it can be inferred that Ukrainian translations of the Bible do not reflect the semantic difference between $\tau \alpha \pi \varepsilon i v o ́ \varsigma$ and $\tau \alpha \pi \varepsilon i v o ́ \varphi \rho \omega v$.

As mentioned above, $\tau \alpha \pi \varepsilon v v o ́ \varsigma$ is used twice in the New Testament with the meaning 'oppressed', 'needy', and 'unfortunate' (in 2 Cor. 7:6 and James 1:9). To convey this meaning, translators mostly resort to words other than смиренний/ сумирний/смирний and покірливий/покірний. So, in 2 Cor. 7:6, apart from смиренний (KLP) and покірний (OH, RT), the word принижений is used (IO, IK), while in James 1:9, we find смиренний in one translation only (KLP), with $n p u$ нижений 'humiliated' (OH), понижений 'abased' (IO), упокорений 'subdued' (RT), низького стану 'of low estate' (IK) being used in the others. These target words accurately correspond to the meaning of $\tau \alpha \pi \varepsilon v v o ́ \varsigma$ in the source text.

To summarize, the most frequent word that is used to render $\tau \alpha \pi \varepsilon \imath v o$ $\varsigma$ in its positive and neutral meaning 'humble in one's mind/heart', 'unarrogant' (in Matt. 11:28, Rom. 12:16, 2 Cor. 10:1, 1 Pet. 5:5, James 4:6) is смиренний (10 occurrences out of 32). However, $60 \%$ of its use is accounted for by the translations of the 19th century (KLP and PM). It should be noted that in Russian translations, $\tau \alpha \pi \varepsilon i v o ́ \varsigma$ in this meaning is mainly rendered by смиренный 'humble', 'meek': particularly, ST resorts to смиренный (or its shortened form смирен) in all of the 6 cases, while KB uses смиренный/смирен in 5 cases, and скромный in 1 case (2 Cor. 10:1). The second most frequent lexeme покірний ( 8 occurrences) is primarily featured in RT ( $63 \%$ of its general use): interestingly, in this translation, words with the root смир- are consistently avoided. In the other translations, $\tau \alpha \pi \varepsilon l v o ́ \varsigma$ (in its positive and neutral meaning) is rendered by сумирний (6 occurrences, with 5 of them in $\mathrm{OH})$, покірливий (3 occurrences), смирний (2 occurrences, only in KLP), слухняний (1 occurrence), лагідний (1 occurrence), скромний (1 occurrence). The use of смиренний (2 occurrences in KLP) and покірний (1 occurrence in each of $\mathrm{OH}$ and RT) to render $\tau \alpha \pi \varepsilon \imath v o ́ \varsigma$ in its negative meaning indicates that the contextual meanings of the source word were not taken into consideration by the translators.

To verify the results, we have also compared the rendition of $\tau \alpha \pi \varepsilon l v o \varphi \rho o \sigma v v v$ and $\tau \alpha \pi \varepsilon i v \omega \sigma l \varsigma$ (the derivatives of $\tau \alpha \pi \varepsilon i v o ́ \varsigma$ ) in Ukrainian translations of the New Testament. The former lexeme marks a moral virtue and has the meaning of 'humility of mind/heart', 'submission to God', while the latter lexeme, apart from 'humility', also marks ‘humiliation', 'lowly position' (just as $\tau \alpha \pi \varepsilon \imath v o ́ \varsigma$ ). The word $\tau \alpha \pi \varepsilon l v o \varphi \rho о \sigma v v \eta \eta$ is rendered in the translations as follows:

1) Acts 20:19: покора 'obedience', 'submission' (IO, IK, OH, KLP), покірливість 'obedience', 'meekness' (RT); 
2) Phil. 2:3: покора (IO, IK, RT), сумирність 'meekness', 'submissiveness' $(\mathrm{OH})$, сумирний розум 'humble mind', 'meek mind' (KLP);

3) Col. 2:18: покора (IO, IK, OH, RT, KLP);

4) Col. 2:23: покора (IO, IK, RT, KLP), сумирна мудрість 'humility/ humbleness of mind' $(\mathrm{OH})$;

5) Col. 3:12: покора (IO), покірність 'submission', 'submissiveness' (RT), смиренність 'meekness', 'humility', 'humbleness' (IK), смирність 'meekness', 'submissiveness' (KLP), сумирна мудрість (OH);

6) Eph. 4:2: покора (IO, IK), покірність (RT), сумирна мудрість (OH), смирнота 'meekness', 'submissiveness' (KLP).

7) 1 Pet. 5:5: покора (IO, RT), покірливість (IK), сумирна мудрість (OH), смирність (KLP).

Based on the above data, we can infer that the most frequent equivalent of $\tau \alpha-$

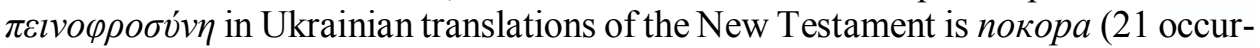
rences out of 35), not смиренність, as would be expected given that this word is included in the common Old Slavic lexis and given the frequent use of смиреннии as the equivalent of $\tau \alpha \pi \varepsilon v v o ́ s$. Interestingly, it is only I. Ohiienko who consistently uses покора as the equivalent of $\tau \alpha \pi \varepsilon i v o \varphi \rho о \sigma v ́ v \eta$ throughout the translation, which

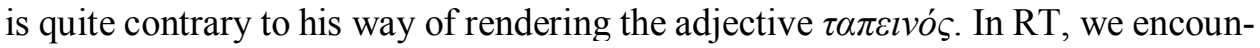
ter cognate lexemes покора (4 occurrences), покірність (2 occurrences) / покірливість (1 occurrence): this translator also tends to use покірний to render $\tau \alpha \pi \varepsilon i v o ́ \varsigma$ ( 6 out of 8 occurrences of the general use). IK resorts to покора in 4 cases, along with смиренність, which is used only once. The greatest variation of target words, however, can be observed in KLP translation, which features the forms that are uncommon in modern Ukrainian language: смирність, смирнота, смирний as the equivalents of $\tau \alpha \pi \varepsilon v v o ́ s$. Besides, KLP and $\mathrm{OH}$ make an attempt to convey the internal form of the word $\tau \alpha \pi \varepsilon l v o \varphi \rho о \sigma v ́ v \eta$ rendering it by сумирна мудрість (3 осcurrences in $\mathrm{OH}$ ) or сумирний розум (1 occurrence in KLP) since the root $\varphi \rho о$ includes the semes 'mind', 'wisdom', 'reason' (cf. Ancient Greek $\varphi \rho \eta \dot{\eta} v$ 'mind', $\varphi \rho o ́ v \imath \mu о \varsigma$ 'reasonable', 'of sound mind', $\varphi \rho o ́ v \eta \mu \alpha$ 'sound mind', 'discretion', 'judgment', $\varphi \rho o ́ v \eta \sigma \iota \varsigma$ 'thinking', 'reason'). The tendency toward calquing the internal form of the lexeme $\tau \alpha \pi \varepsilon \imath v o \varphi \rho o \sigma v v \eta$ is typical of Russian translations, e.g. in ST,

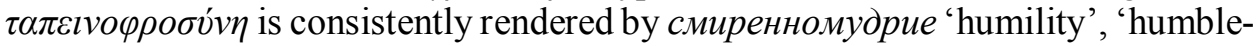
ness of mind' throughout the New Testament.

In Luke 1:48, the word $\tau \alpha \pi \varepsilon i v \omega \sigma \iota \varsigma$ in the meaning 'humility' is rendered either by покора (IO, IK, OH, RT) or смирення 'humility' (KLP, PM). Thus, покора

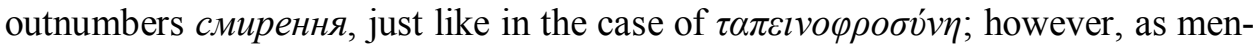
tioned above, the latter is rendered by various words, derived from the Old Slavic roots sbmer-/sbmir-. In the other cases, $\tau \alpha \pi \varepsilon i v \omega \sigma l \varsigma$ used in the meaning 'humiliation', 'oppression' is rendered by приниження 'humiliation' (Acts 8:33 - IO, IK, RT, KLP; James 1:10 - OH, RT), пониження 'abasement' (Phil. 3:21 - IO, RT; James 1:10-IO, IK), зневага 'despise' (Acts 8:33-OH). It is only in KLP that смирення is used twice as an equivalent of $\tau \alpha \pi \varepsilon i v \omega \sigma l \varsigma$ in the negative meaning (with the same being true for the adjective смиренний). 
7. In conclusion, the translations of the 19th century (PM, KLP) tend to use the words смиренний and смирення (as well as the obsolete смирний, смирнота, смирність) to convey the positive/neutral (and sometimes also the negative) semantics of $\tau \alpha \pi \varepsilon \imath v o ́ s$ and its noun derivatives, while the translations of the second half of the 20th and the beginning of the 21 st centuries (IO, IK, OH, RT) favour the lexeme покірний and its cognates покірливий, покора, покірність. However, the latter also resort to the words сумирний, смиренний and the corresponding nouns сумирність and смиренність (but not смирення). Apart from several occurrences in $\mathrm{OH}$ and KLP, most translations do not discern between the Greek synonyms $\tau \alpha \pi \varepsilon \imath v o ́ \varsigma / \tau \alpha \pi \varepsilon l v o ́ \varphi \rho \omega v$ and $\tau \alpha \pi \varepsilon i v \omega \sigma l \varsigma / \tau \alpha \pi \varepsilon \imath v o \varphi \rho o \sigma o ́ v \eta$ in selecting the target words to convey their positive/neutral meaning (contrary to the Russian ST where these words are rendered by смиренный/смиренномудрый and смирение/ смиренномудрие).

In modern translations, $\tau \alpha \pi \varepsilon l v o ́ \varsigma$ and $\tau \alpha \pi \varepsilon i v \omega \sigma l \varsigma$ in the negative meaning are rendered by other linguistic means, mostly in correspondence with the contextual meaning of the source words, i.e. by the words принижений, понижений, упокорений (and occasionally, покірний) and приниження, пониження, зневага. Contrariwise, KLP tends to disregard the contextual meanings of the above source words, just like ancient translations do, e.g. the Latin Vulgate (humilitas) and the Old Slavic Bible (смирение): therefore, we consistently encounter смиренний and смирення as the equivalents of $\tau \alpha \pi \varepsilon l v o ́ \varsigma / \tau \alpha \pi \varepsilon i v \omega \sigma l \varsigma$ used in the negative meaning. The variability of Ukrainian equivalents of the Greek $\tau \alpha \pi \varepsilon l v o ́ \varsigma$ in Ukrainian translations of the New Testament can be considered as indicative, on the one hand, of the absence of fixed theological terms for humility, which are marked by the regularity of use, and, on the other hand, of the ongoing search for properly selected Ukrainian equivalents of the word $\tau \alpha \pi \varepsilon \imath v o ́ \varsigma$ and its derivatives in order to avoid calquing the Russian equivalents.

\section{Translations}

IK = Хоменко Іван (пер.): Святе Письмо Старого та Нового Завіту. Львів, 2007.

IO = ОгІєнко Іван (пер.): Біблія або Книги Святого Письма Старого і Нового Заповimy. Київ, 2004.

KВ = БЕзОБРАЗОВ Кассиан (пер.): Новый Завет. http://azbyka.ru/otechnik/Kassian_Bez obrazov/novyj-zavet-perevod-pod-red-ep-kassiana-bezobrazova.

KLP = Кулшш П., ЛЕвицький І., Пулюй I. Сьвяте Письмо Старого і Нового Завіту. Київ, 2003.

NA = Nestle Eberhard, Nestle Erwin, Aland Barbara, Aland Kurt, Karavidopoulos Johannes (ed.): Novum testamentum Graece. Stuttgart, 2016.

$\mathrm{OH}=$ ГижА Олександр: Біблія. Новітній переклад украӥнською літературною мовою. http://www.ukrbible.com.

PM = МорАчевський Пилип (пер.): Свангеліє українською мовою. http://www.parafia. org.ua/biblioteka/unikalni-rukopysy/jevanhelije-morachevskoho.

RT = Турконяк Рафаїл (пер.): Біблія. Новий переклад. Київ, 2011.

$\mathrm{ST}=$ Библия. Русский синодальный перевод. http://www.bibleonline.ru/bible/rus. 


\section{Sources}

AlAND = Aland Kurt: Vollständige Konkordanz zum griechischen Neuen Testament 1-2. Berlin-New York, 1983.

DELG = Chantraine Pierre: Dictionnaire étymologique de la langue grecque. Histoire des mots. T. 1-4. Paris, 1968-1977.

DRS = ДвоРецКий И. Х. Древнегреческо-русский словарь. Т. 1-2. Москва, 1958.

ESRJa = ФАСмЕР Макс: Этимологический словарь русского языка. Т. 1-4. Москва, 1964-1973.

ESUM = Етимологічний словник української мови. Т. 1-7. Київ, 1983-2006.

GEW = FRISK H. Griechisches etymologisches Wörterbuch 1-3. Heidelberg, 1960-1972.

GRS 1991 = Вейсман А. Д. Греческо-русский словарь. Москва, 1991.

LAMPe 1961 = LAMPE G. W. H. Greek Patristic Lexicon. Oxford, 1961.

LSJ 1996 = LIDDELL Henry, ScOTT Robert, JONES Henry: Greek-English Lexicon. Oxford, 1996.

Strong 1890 = Strong James: A Concise Dictionary of the Words in the Hebrew Bible. Nashville, 1890.

SUM = Словник української мови. Т. 1-11. Київ, 1970-1980.

TAYER 1886 = TAYER Joseph: Greek-English Lexicon of the New Testament. New York, 1886.

\section{References}

BeEKMAN-CALlow 1994 = БИКман Д., КЕЛЛоу Д. Не искажая слова Божьего. Принцииь перевода и семантического анализа Библии. Санкт-Петербург, 1994.

BlaCk 1985 = Black David: Paul and Christian Unity. A Formal Analysis of Philippians 2:1-4. Journal of the Evangelical Theological Society 28 (1985): 299-308.

ButTon 2005 = ButTon Mark: "A Monkish Kind of Virtue"? For and against Humility. Political Theory 33 (2005): 840-868.

CAMERON 1999 = CAMERON Averil: On the Grace of Humility. Theology 102 (1999): 97104.

DAwes 1988 = DAwES Stephen: Walking Humbly: Micah 6.8 Revisited. Scottish Journal of Theology 41 (1988): 331-340.

DAwes 1991 = DAwes Stephen: Ānāwâ in Translation and Tradition. Vetus Testamentum 41 (1991): 38-48.

Dickson 2011 = DiCKSON John: Humilitas. A Lost Key to Life, Love, and Leadership. Grand Rapids, 2011.

DickSON-Rosner 2004 = DickSOn John, Rosner Brian: Humility as a Social Virtue in the Hebrew Bible? Vetus Testamentum 54 (2004): 459-479.

Dовко 2013 = Доько Т. Д. Феноменологія смирення. Гуманітарні студї. Вип. 20. Київ, 2013. 52-62.

Flanagan 1990 = Flanagan Owen: Virtue and Ignorance. Journal of Philosophy 87 (1990): 420-428.

FoulCHER 2015 = FoulCHER Jane: Reclaiming Humility. Four Studies in the Monastic Tradition. Collegeville, 2015.

GoRBACHEVSKII 1996 = ГоРБАЧЕВСКий А. А. О соотношении между понятиями «буквальный» и «адекватный» перевод. В кн.: Перевод Библии. Лингвистические, историко-культурные и богословские аспекты. Москва, 1996. 135-144. 
GREEN 1973 = GREEN Ronald: Jewish Ethics and the Virtue of Humility. The Journal of Religious Ethics 1 (1973): 53-63.

Hare 1996 = Hare Stephen: The Paradox of Moral Humility. American Philosophical Quarterly 33 (1996): 235-241.

KARPOV 2003 = КАРПOВ В. И. Буквализм древних переводов Библии и проблема адекватной передачи семантики исходного текста. Вестник Воронежского государственного университета 2003/2: 45-49.

Kellenberger 2010 = Kellenberger James: Humility. American Philosophical Quarterly 47 (2010): 321-336.

Косн 2013 = Коч Н. Ориентационная метафора «верх /низ» и концепт «гордыня /смирение» в христианской лингвокультуре Древней Руси. Науковий вісник Херсонського державного університету 18 (2013): 106-111.

KONOVALENKO 2014 = КоновАЛЕнко Т. Г. Смирение как ключевой концепт православной языковой картины мира. Филологические науки. Вопросы теории и практики. № 7. Ч. 2. Тамбов, 2014. 101-104.

KoRENEVA $2010=$ КоРеHEBA Ю. В. Семантика смирения в агиографическом тексте: историко-лексикографический аспект. Вестник Нижегородского университета им. Н. И. Лобачевского. № 4. Ч. 2. Нижний Новгород, 2010. 560-563.

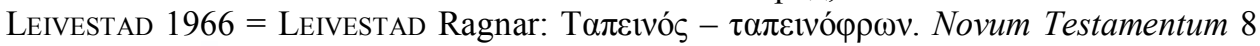
(1966): 36-47.

LOBACHOVA 2015 = ЛоБАчовА I. M. Лінгвостилістичні особливості українських перекладів Біблії у ХX столітті. Філологічні трактати. Т. 7. № 2. Суми, 2015. 89-96.

MATSKIV 2006 = МАцькІв П. В. Українські переклади Біблії: семасіологічний аспект. Вісник Сумського державного університету 2006/1: 168-172.

Moroz 2012 = Мороз Т. В. Спільні риси українського перекладу Біблії 1903 року та мови творів Івана Франка: лексика високого стилю. Дослідження з лексикології $i$ граматики української мови. Вип. 12. Дніпропетровськ, 2012. 95-103.

Nelson 1985 = Nelson Daniel: The Virtue of Humility in Judaism. A Critique of Rationalist Hermeneutics. The Journal of Religious Ethics 13 (1985): 298-311.

Niмcнuк 2011 = НІмчук В. Лексеми раб і слуга в українських перекладах Нового Завіту. Украӥнська мова 2011/1: 3-27.33

Plato 1967 = Plato in Twelve Volumes. Vol. 10. Laws. Cambridge, 1967.

RICHARDS 1988 = RichARDS Norvin: Is Humility a Virtue? American Philosophical Quarterly 25 (1988): 253-259.

SCHLESINGer 1993 = Schlesinger George: Humility. Tradition. A Journal of Orthodox Jewish Thought 1993/3: 4-12.

Sharbaugh 2013 = Sharbaugh Patricia: The New Moses and the Wisdom of God. A Convergence of Themes in Matthew 11:25-30. Horizons 40 (2013): 199-217.

Statman 1992 = Statman Daniel: Modesty, Pride, and Realistic Self-Assessment. Philosophical Quarterly 42 (1992): 420-438.

SzRAM 2012 = SzRAm Mariusz: Terminologia dotycząca pokory i pychy w pismach greckich Ojców Kościoła IV wieku. Vox Patrum 58. Lublin, 2012. 327-342.

VolT 2003 = Volt Ivo: Aspects of Ancient Greek Moral Vocabulary. Illiberality and Servility in Moral Philosophy and Popular Morality. Trames 7 (2003): 67-82. 